\title{
Impact of Room Air Resuscitation on Early Growth Response Gene-1 in a Neonatal Piglet Model of Cerebral Hypoxic Ischemia
}

\author{
MELISSA M. TYREE, CLIFTON DALGARD, AND J. TIMOTHY O'NEILL \\ Department of Pediatrics [M.M.T., J.T.O.], Department of Neurology [C.D.], Uniformed Services University of the Health Sciences, \\ Bethesda, Maryland, 20814
}

\begin{abstract}
Early growth response gene-1 (Egr-1) is up-regulated by hypoxia-ischemia (HI) and reactive oxygen species (ROS) in adult animals, functioning as a master switch in inflammation and thrombogenesis. We hypothesized that resuscitation from $\mathrm{HI}$ with $100 \% \mathrm{O}_{2}$ would result in greater Egr-1 expression, ROS, and cell death (CD) in the brains of newborn piglets than $21 \% \mathrm{O}_{2}$. Two control groups breathed $21 \% \mathrm{O}_{2}$ for $1 \mathrm{~h}$ followed by $21 \%$ or $100 \% \mathrm{O}_{2}$ for $1 \mathrm{~h}$. Two HI groups underwent carotid artery occlusion and breathed $8-12 \%$ $\mathrm{O}_{2}$ for $1 \mathrm{~h}$ followed by occlusion release and $21 \%$ or $100 \% \mathrm{O}_{2}$ for $1 \mathrm{~h}$. Brain Egr-1 mRNA and protein were analyzed via quantitative PCR and Western blot. CD and ROS were measured by fluorescence microscopy. Egr-1 mRNA expression increased throughout the brain in response to $\mathrm{HI}$ with regional heterogeneity, but protein levels did not. Resuscitation with $100 \%$ oxygen did not cause any additional Egr-1 mRNA, Egr-1 protein, CD, or ROS production as compared with $21 \%$ oxygen. There was no difference in physiologic recovery after $\mathrm{HI}$ with room air compared with $100 \% \mathrm{O}_{2}$ resuscitation. However, $100 \% \mathrm{O}_{2}$ administration was associated with increased CD in the brainstem independent of $\mathrm{HI}$. Therefore, $100 \% \mathrm{O}_{2}$ may have been toxic to some brainstem cells and potentially have significance in long-term neurologic sequelae seen after neonatal HI/resuscitation. Egr-1 protein levels may be tightly regulated in an attempt to diminish neurotoxicity or to enhance plasticity at this stage of development. (Pediatr Res 59: 423-427, 2006)
\end{abstract}

$\mathrm{E}$ gr-1 is a member of the family of immediate-early genes that encode for transcription factors and are known to be acutely up-regulated within minutes of stimulation by multiple forms of tissue stress and injury (1). In adult animal models, cerebral $\mathrm{HI}$ is associated with early (30 min) and sustained (3 d) increases in Egr-1 (2,3). Because persistent expression of Egr-1 mRNA expression was found in areas most vulnerable to ischemia, it could be a result or a cause of CD. ROS are particularly potent stimuli capable of inducing Egr-1 expression (4). Egr-1 has been termed the "master switch" responsible for coordinating the up-regulation of diverse gene fam-

Received April 18, 2005; accepted October 14, 2005

Correspondence: J. Timothy O'Neill, Ph.D., Department of Pediatrics, Uniformed Services, University of the Health Sciences, Bldg. C, Room 1069B, 4301 Jones Bridge Road, Bethesda, MD 20814; e-mail: joneill@usuhs.mil

The opinions or assertions contained herein are the private views of the authors and are not to be construed as official or to reflect the opinions of the Uniformed Services University of the Health Sciences, the Air Force, or Department of Defense.

Supported by a 2002 Young Investigator Award Research Grant, American Academy of Pediatrics, Neonatal Resuscitation Program, and a research grant from the National Naval Medical Center, Bethesda MD.

DOI: 10.1203/01.pdr.0000199908.30751.ef ilies known to play a crucial role in the maladaptive response and vascular dysfunction seen in the lung subjected to HI/R (5).

Recent research has attempted to determine whether resuscitation should be performed with $21 \%$ rather than $100 \%$ oxygen in an attempt to limit oxygen availability to tissues in the immediate reperfusion period and minimize the potential for the generation of ROS that exacerbate the expression of Egr-1 and CD or injury. Hypoxia with subsequent resuscitative hyperoxia warrants special consideration in the neonate due to its impact on disease entities unique to the newborn.

This study was designed to evaluate Egr-1 expression in response to resuscitation after $\mathrm{HI}$. We hypothesized that HI/R would increase the expression of Egr-1 and that $100 \% \mathrm{O}_{2}$ would result in greater Egr-1 expression than room air. We evaluated the expression of Egr-1 by analyzing the content of mRNA and protein in the brains of newborn piglets. To evaluate the potential association of Egr-1 and cell injury, we evaluated acute CD. In addition, we measured ROS content in the same areas of the brain after HI/R with either $21 \%$ or $100 \% \mathrm{O}_{2}$.

\section{MATERIALS AND METHODS}

Animal preparation. All protocols were approved by the USUHS Institutional Animal Care and Use Committee. Newborn piglets ( $<10 \mathrm{~d}$ old, $n=39)$ were sedated with an intraperitoneal dose of $\alpha$-chloralose $(50 \mathrm{mg} / \mathrm{kg})$ and urethane $(400 \mathrm{mg} / \mathrm{kg})$, intubated, and ventilated with an Infant Star ventilator (Mallinckrodt, St. Louis, MO). Venous access was established with a 22gauge catheter via percutaneous venipuncture and anesthesia was achieved with additional i.v. bolus doses of $\alpha$-chloralose ( $25 \mathrm{mg} / \mathrm{kg}$ ) and urethane (200 $\mathrm{mg} / \mathrm{kg}$ ). End-tidal $\mathrm{CO}_{2}$ was monitored (BCI, Waukesha, WI) and ventilator settings were changed to maintain the arterial partial pressure of $\mathrm{CO}_{2}$ between 35 and $45 \mathrm{~mm} \mathrm{Hg}$. Rectal temperature was monitored and maintained between 38 and $39^{\circ} \mathrm{C}$ using a heat lamp and water heating pad. Biparietal electrodes were placed for EEG monitoring. Femoral arterial and venous catheters were placed via cut-down for systemic blood pressure monitoring and fluid and drug administration, respectively. Bilateral carotid artery cut-downs were performed. Umbilical tape (1/8") was placed around each common carotid artery and a piece of Tygon tubing (3/32" diameter) was slipped over the tape to be advanced to reversibly occlude the arteries. Systemic arterial pressure, EEG activity, and end-tidal $\mathrm{CO} 2$ were continuously recorded and digitally stored (ADInstruments, Colorado Springs, CO).

At the completion of surgery, each animal was heparinized (500 U/kg i.v.), paralyzed with pancuronium bromide $(0.1 \mathrm{mg} / \mathrm{kg})$, and started on a $\mathrm{D}_{5} \mathrm{~W}$ infusion at $4 \mathrm{~mL} / \mathrm{kg} / \mathrm{h}$. Further doses of pancuronium were given as needed for

Abbreviations: aCSF, artificial cerebrospinal fluid; CD, cell death; DCFA, 5-chloromethyl-2,7-dichlorodihydrofluorescein diacetate; Egr-1, early growth response gene-1; HI, hypoxia-ischemia; HI/R, hypoxia-ischemia and resuscitation; MAP, mean arterial blood pressure; PI, propidium iodide; ROS, reactive oxygen species 
paralysis. Chloralose and urethane anesthesia was maintained with a schedule developed during surgery, about 10 and $80 \mathrm{mg} / \mathrm{kg} / \mathrm{h}$, respectively.

Experimental protocol. After surgical preparation and $60 \mathrm{~min}$ of postsurgical stabilization on $21 \% \mathrm{O}_{2}$, animals were randomized into four groups. The two control groups breathed $21 \% \mathrm{O}_{2}$ for $1 \mathrm{~h}\left(\mathrm{~T}_{0}-\mathrm{T}_{60}\right)$ with no carotid occlusion as a sham insult, and then received either $21 \% \mathrm{O}_{2}(\mathrm{C} 21)$ or $100 \%$ $\mathrm{O}_{2}(\mathrm{C} 100)$ for $1 \mathrm{~h}\left(\mathrm{~T}_{60}-\mathrm{T}_{120}\right)$. Animals in the experimental groups were made hypoxic-ischemic by reduction of inspired $\mathrm{O}_{2}$ to $8-12 \%$ and bilateral common carotid artery occlusion for $1 \mathrm{~h}\left(\mathrm{~T}_{0}-\mathrm{T}_{60}\right)$. The occlusion was then released and animals were resuscitated with either $21 \%(\mathrm{H} 21)$ or $100 \% \mathrm{O}_{2}$ (H100) for $1 \mathrm{~h}\left(\mathrm{~T}_{60}-\mathrm{T}_{120}\right)$ (Fig. 1). The HI insult was required to induce a 10 $\mathrm{mEq} / \mathrm{L}$ decrease in base excess and a minimum of $30 \mathrm{~min}$ of isoelectric EEG activity for the piglet to be included in the study. Pilot data demonstrated that both hypoxia of $8 \% \mathrm{O}_{2}$ and ischemia induced by bilateral carotid artery occlusion were required to induce $\mathrm{HI}$ as defined above. Our pilot data also showed that fixed $8 \% \mathrm{O}_{2}$ resulted in profound hypotension and asystole if the MAP remained $<20 \mathrm{~mm} \mathrm{Hg}$. Thus, titration of $\mathrm{O}_{2} \%$ from 8 to 12 was required to meet $\mathrm{HI}$ criteria and to keep MAP $>20 \mathrm{~mm} \mathrm{Hg}$ to prevent death from cardiovascular collapse.

Arterial blood samples were collected at the start of the protocol $\left(\mathrm{T}_{0}\right)$, before initiating resuscitation $\left(\mathrm{T}_{60}\right)$, and just before euthanasia $\left(\mathrm{T}_{120}\right)$, and analyzed for $\mathrm{pH}, \mathrm{PCO}_{2}, \mathrm{Po}_{2}$, base excess, and lactate (Nova M7 blood gas analyzer, Waltham, MA). At the start of the resuscitation phase, all animals received a $\mathrm{NaHCO}_{3}$ infusion over $20 \mathrm{~min}$, calculated to fully correct the base deficit.

A predetermined algorithm was followed to direct additional resuscitative measures. Escalation to the next intervention was indicated if the MAP remained $<50 \mathrm{~mm} \mathrm{Hg}$. If the MAP was $<50 \mathrm{~mm} \mathrm{Hg}$, a normal saline bolus of $10 \mathrm{~mL} / \mathrm{kg}$ was given up to two times, followed by the administration of dopamine at $10 \mu \mathrm{g} / \mathrm{kg} / \mathrm{min}$, increased in increments of $10 \mu \mathrm{g} / \mathrm{kg} / \mathrm{min}$ up to a maximum of $30 \mu \mathrm{g} / \mathrm{kg} / \mathrm{min}$. A MAP of $>50 \mathrm{~mm} \mathrm{Hg}$ was selected to ensure a cerebral perfusion pressure adequate to allow brain reperfusion after $\mathrm{HI}(6)$. At the end of resuscitation $\left(\mathrm{T}_{120}\right)$ an 18-gauge angiocatheter was placed in each common carotid. Animals were killed with an overdose of anesthesia ( $\alpha$ Chloralose, $250 \mathrm{mg} / \mathrm{kg}$ and urethane $2 \mathrm{~g} / \mathrm{kg}$, respectively) and $50 \mathrm{~mL}$ of ice-cold aCSF ( $\mathrm{NaCl} 122.6, \mathrm{NaHCO}_{3} 26.2, \mathrm{CaCl} 1.8, \mathrm{KCl} 3.0, \mathrm{MgSO}_{4} 0.4$, $\mathrm{NaH}_{2} \mathrm{PO}_{4} 0.5$, and dextrose $3.7 \mathrm{mM}$ ) was rapidly infused into each carotid artery. The cortex, hippocampus, and brainstem were rapidly extracted and placed in aCSF $\left(0^{\circ} \mathrm{C}\right)$ bubbled with a mixture of room air and $5 \% \mathrm{CO}_{2}$. Tissue was then placed in either aCSF with fluorescent reagents for ROS and CD labeling, RNAlater (stored at $-80^{\circ} \mathrm{C}$; Ambion, Austin, TX ) for total RNA extraction, or T-PER (tissue protein extraction reagent, Pierce, Rockford, IL) $\left(0^{\circ} \mathrm{C}\right)$ for immediate protein extraction.

Resuscitation score. A resuscitation score was devised as a means to evaluate the degree of resuscitative measures required to maintain a MAP $>50 \mathrm{~mm} \mathrm{Hg}$. This scale was created based on the algorithm described above but has not been validated by correlation with long-term outcome. The scoring system was comprised of a perfect score of 7 , with the loss of one point for each of the following: normal saline bolus of $10 \mathrm{~mL} / \mathrm{kg}$, dopamine increase of $10 \mu \mathrm{g} / \mathrm{kg} / \mathrm{min}, \mathrm{MAP}<50 \mathrm{~mm} \mathrm{Hg}$ at $\mathrm{T}_{120}$, no return of EEG activity by $\mathrm{T}_{120}$.

Propidium iodide, carboxy-dichlorofluorescein fluorescence imaging. Cortex, hippocampus, and brainstem slices $(300 \mu \mathrm{m})$ were created using a Mcllwain tissue chopper and incubated in $3 \mathrm{~mL}$ of aCSF bubbled with room air and $5 \% \mathrm{CO}_{2}$ containing PI $(10 \mu \mathrm{g} / \mathrm{mL})$ and DCFA $(5 \mu \mathrm{g} / \mathrm{mL})$ at room

\begin{tabular}{|c|c|c|}
\hline $\mathrm{C} 21$ & $21 \% \mathrm{O} 2$ & $21 \% \mathrm{O} 2$ \\
\hline $\mathrm{C} 100$ & $21 \% \mathrm{O} 2$ & $100 \% \mathrm{O} 2$ \\
\hline \multirow[t]{2}{*}{ H21 } & $8-12 \% \mathrm{O} 2$ & $21 \% \mathrm{O} 2$ \\
\hline & Carotid Ligation & \\
\hline \multirow[t]{2}{*}{ H100 } & $8-12 \% \mathrm{O} 2$ & $100 \% \mathrm{O} 2$ \\
\hline & Carotid Ligation & \\
\hline
\end{tabular}

Figure 1. Treatment groups (C21, C100, H21, and H100) and experimental time course. $\mathrm{T}_{0}-\mathrm{T}_{60}$ comprises the sham or $\mathrm{HI}$ insult phase, and $\mathrm{T}_{60}-\mathrm{T}_{120}$ comprises the resuscitation phase: $\mathrm{C} 21=$ sham insult, $21 \% \mathrm{O}_{2}$ resuscitation $(n=7) ; \mathrm{C} 100=$ sham insult, $100 \% \mathrm{O}_{2}$ resuscitation $(n=7) ; \mathrm{H} 21=\mathrm{HI}$ insult; $21 \% \mathrm{O}_{2}$ resuscitation $(n=7) ; \mathrm{H} 100=\mathrm{HI}$ insult; $100 \% \mathrm{O}_{2}$ resuscitation $(n=7)$. temp for 5 min in a dark incubator (Molecular Probes, Eugene, OR). After incubation, slices were washed three times with aCSF, placed on slides, and viewed with a DMRXA fluorescence microscope (Leica, Wetzlar, Germany) at $10 \times$ magnification. PI was read with a rhodamine filter (excitation $543 \mathrm{~nm}$, emission $590 \mathrm{~nm}$ ), and DCFA was read with a FITC filter (excitation $480 \mathrm{~nm}$, emission $527 \mathrm{~nm}$ ). Digital images of a standardized rectangular area within the region of interest were obtained with a SPOT-cooled CCD camera. Regions of interest were defined as the CA1/dentate junction in the hippocampus, the gray/white matter junction rostral to the central sulcus in the cortex, and the dorsolateral aspect of the rostral medulla in the brainstem. Images were optimized with Tiffany software (CaffeineSofware) and staining per unit area was quantified using Mathematica (Wolfram Research, Champaign, IL) and custom-designed software developed at the USUHS.

Reverse transcription and quantitative PCR analysis. Total RNA was isolated using the RNeasy Mini Kit (QIAGEN, Valencia, CA), and (5 $\mu \mathrm{g}$ ) was reverse-transcribed using the high-capacity cDNA archive kit. Quantitative PCR (qPCR) analysis was performed using iQ SYBR Green Supermix (Bio-Rad, Hercules, CA) and the MyiQ Single-Color Real-Time PCR Detection System (Bio-Rad). After optimization, triplicate reactions were performed with averages obtained only if $C_{T}$ values were \pm 0.5 . The following forward and reverse sets of primers were used at $300 \mathrm{nM}$ : for Egr-1 (GenBank \# AJ238156) (forward = 5' - CAGACCAGAAGCCTTTCCAG-3' and reverse $=5^{\prime}$-CTGGGACTGGTAGGTGGTGT-3') and for HPRT (GenBank \# AF143818) (forward $=5^{\prime}$-CCGAGGATTTGGAAAAGGTT- $3^{\prime}$ and reverse $=5^{\prime}$-AGAGGGCTACGATGTGATGG- ${ }^{\prime}$ ). Single-product amplifications were verified by multicomponent analysis and specific amplification was verified by sequencing. Results are reported as fold change differences normalized to the housekeeping gene HPRT and to the C21 control group.

Western blot analysis. Whole tissue $(1 \mathrm{~g})$ was homogenized in $1 \mathrm{~mL}$ of T-PER. Protein was extracted per protocol of the T-PER Kit (Pierce), and protein concentration determined with the Micro BCA Protein Assay Kit (Pierce). Total protein $(50 \mu \mathrm{g})$ was electrophoresed in 10\% NuPage Bis-Tris gels (Invitrogen, Carlsbad, CA) and transferred to nitrocellulose using $\mathrm{Nu}$ Page reagents (Invitrogen). National Institutes of Health/3T3 mouse whole cell lysate (Santa Cruz Biotechnology Inc., Santa Cruz, CA) was used as a positive control. Nitrocellulose membranes were blocked in 5\% milk/PBS$0.05 \%$ Tween (PBS-T) at room temperature for $1 \mathrm{~h}$ and then incubated with primary antibody overnight at $4{ }^{\circ} \mathrm{C}(\mathrm{Egr}-1588, \mathrm{SC}-110$, rabbit antibody from peptide, 1:1000) (Santa Cruz). Membranes were washed with PBS-T, and incubated with biotinylated secondary antibody (HRP-conjugated donkey, anti-rabbit, 1:1000) (Amersham Pharmacia Biotech, Little Chalfont, Buckinghamshire, UK) made up in 5\% milk/PBS-T. Signal was detected using a chemiluminescent solution (Luminol reagent, Santa Cruz), according to the manufacturer's instructions. The blots were then exposed to film (Biomax MS Film, Eastman Kodak, Rochester, NY) for $3 \mathrm{~min}$. Developed films were scanned using PhotoShop 7.0 (Adobe Systems, Inc., San Jose, CA) and band intensity was analyzed using Scion Image for Windows (Frederick, M.D.) and normalized to $\beta$-actin.

Statistics. Continuous data were analyzed with a two-way ANOVA (HI versus $\mathrm{O}_{2} \%$ ) with the Tukey multiple comparison test to determine differences among means, and are reported as mean \pm SEM. Resuscitation score, reported as median and quartile ranges, was analyzed using Kruskal-Wallis ANOVA on ranks. Significance was set at $p<0.05$. Standard least-squares linear regression analysis was performed. All statistics were done using SigmaStat 3.1 (Aspire Software International, Leesburg, VA).

\section{RESULTS}

Experimental model. Thrity-nine piglets were studied. Five died during $\mathrm{HI}$, four had an isoelectric EEG $<30 \mathrm{~min}$, one had a decrease in base $<10 \mathrm{mEq} / \mathrm{L}$, one was not included in analysis due to lost data. The remaining 28 piglets were analyzed ( $n=7$ /group). Baseline physiologic parameters were within normal limits and similar amongst all groups at baseline $\left(\mathrm{T}_{0}\right)$ (Table 1). These physiologic parameters did not change in the control groups but were dramatically altered in the $\mathrm{HI}$ groups. $\mathrm{HI}$ induced a significant decrease in MAP of $>50 \mathrm{~mm} \mathrm{Hg}$, a decrease in $\mathrm{pH}$ of 0.1 units, an increase in serum lactate of near $10 \mathrm{mM}$, and a decrease in base excess of $>10 \mathrm{mEq} / \mathrm{L}$. The lowest arterial partial pressures of $\mathrm{O}_{2}\left(\mathrm{PaO}_{2}\right)$ measured were $29 \pm 2.1(\mathrm{H} 21)$ and $31 \pm 2.6$ (H100) $\mathrm{mmHg}$. EEG activity was isoelectric for $45 \pm 3.1(\mathrm{H} 21)$ and $44 \pm 3.0$ 
Table 1. Physiologic parameters at $T_{0}, T_{60}$, and $T_{120}$

\begin{tabular}{|c|c|c|c|c|}
\hline & $\mathrm{C} 21$ & $\mathrm{C} 100$ & $\mathrm{H} 21$ & H100 \\
\hline \multicolumn{5}{|l|}{$\mathrm{T}_{0}$} \\
\hline $\mathrm{pH}$ & $7.42 \pm 0.02$ & $7.43 \pm 0.01$ & $7.42 \pm 0.01$ & $7.42 \pm 0.01$ \\
\hline $\mathrm{PaO}_{2}(\mathrm{~mm} \mathrm{Hg})$ & $92 \pm 2.7$ & $93 \pm 2.8$ & $90 \pm 3.2$ & $91 \pm 3.5$ \\
\hline Base excess $(\mathrm{mEq} / \mathrm{L})$ & $2.1 \pm 0.4$ & $3.3 \pm 0.5 \neq$ & $2.4 \pm 0.4$ & $3.8 \pm 0.5 \neq$ \\
\hline Lactate $(\mathrm{mmol} / \mathrm{L})$ & $1.5 \pm 0.2$ & $1.2 \pm 0.2$ & $1.2 \pm 0.1$ & $1.5 \pm 0.2$ \\
\hline MAP (mm Hg) & $71 \pm 4.8$ & $72 \pm 2.7$ & $75 \pm 5.8$ & $75 \pm 5.5$ \\
\hline $\mathrm{PaO}_{2}(\mathrm{~mm} \mathrm{Hg})$ & $90 \pm 1.0$ & $92 \pm 4.0$ & $50 \pm 6.0^{*}$ & $53 \pm 4.3^{*}$ \\
\hline $\mathrm{O}_{2}$ sat $(\%)$ & $99 \pm 0.4$ & $99 \pm 0.5$ & $64 \pm 8.8^{*}$ & $64 \pm 8.7^{*}$ \\
\hline Base excess $(\mathrm{mEq} / \mathrm{L})$ & $1.6 \pm 0.7$ & $3.2 \pm 0.7$ & $-8.4 \pm 1.1^{*}$ & $-9.0 \pm 1.3^{*}$ \\
\hline Lactate $(\mathrm{mmol} / \mathrm{L})$ & $1.5 \pm 0.3$ & $1.4 \pm 0.2$ & $9.0 \pm 0.9 *$ & $11.3 \pm 2.2^{*}$ \\
\hline MAP (mm Hg) & $71 \pm 4.5$ & $71 \pm 3.2$ & $18 \pm 2.9 *$ & $18 \pm 2.4^{*}$ \\
\hline \multicolumn{5}{|l|}{$\mathrm{T}_{120}$} \\
\hline Lactate $(\mathrm{mmol} / \mathrm{L})$ & $1.4 \pm 0.3$ & $1.1 \pm 0.2$ & $4.6 \pm 0.9 *$ & $5.7 \pm 1.3^{*}$ \\
\hline MAP (mm Hg) & $71 \pm 4.7$ & $69 \pm 2.6$ & $55 \pm 5.7^{*}$ & $56 \pm 4.0^{*}$ \\
\hline
\end{tabular}

$*$ Different from control group $p<0.001$.

$\dagger$ Different from room air-resuscitated group $p<0.001$.

$\ddagger$ Different from room air-resuscitated group $p<0.01$.

(H100) minutes. After HI, there were no significant differences in these parameters between the $\mathrm{H} 21$ and $\mathrm{H} 100$ group, indicating that the two groups had received a similar hypoxicischemic challenge before resuscitation. As expected, $\mathrm{PaO}_{2}$ was greater at $\mathrm{T}_{120}$ in animals receiving $100 \% \mathrm{O}_{2}(p<0.001)$. In HI groups, lactate decreased and MAP increased after resuscitation at $\mathrm{T}_{120}(p<0.001)$ but failed to recover to control levels $(p<0.001)$.

Quantitative PCR analysis. Egr-1 mRNA (Fig. 2A) was increased in response to $\mathrm{HI}$ approximately 3 -fold in the cortex, 4- to 5 -fold in the hippocampus, and nearly 15 -fold in the brainstem when compared with the control groups $(p<$ 0.001 ). Administration of $100 \% \mathrm{O}_{2}$ resulted in a $37 \%$ increase in mRNA compared with administration of $21 \% \mathrm{O}_{2}(p<0.01)$ in cortex but did not enhance mRNA after HI. Egr-1 mRNA was weakly but significantly correlated with DCFA $\left(r^{2}=\right.$ $0.45)$ and PI $\left(r^{2}=0.21\right)$ staining only in the hippocampus.
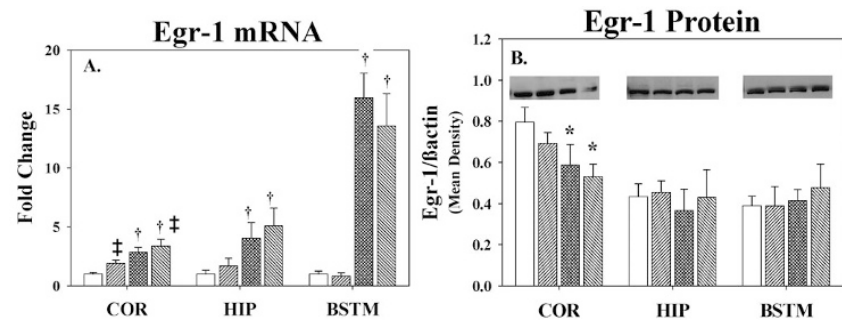

Figure 2. Egr-1 mRNA and protein with HI/R in: cortex (COR), hippocampus $(H I P)$, and brainstem $(B S T M)$. (A) Quantitative Egr-1 mRNA. (B) Egr-1 protein. Open bars represent $\mathrm{C} 21(n=7)$; left-hashed bars represent $\mathrm{C} 100$ $(n=7)$; cross-hashed bars represent $\mathrm{H} 21(n=7)$; right-hashed bars represent H100 $(n=7)$. A sample of a Western blot is shown above each bar. *HI groups (H21 and H100) different from control groups (C21 and C100; $p<$ $0.05)$. $\dagger$ HI groups different from control groups $(p<0.001)$. $\$ 100 \% \mathrm{O}_{2}$ groups different from $21 \% \mathrm{O}_{2}$ groups $(p<0.02)$.
Western blot analysis. In contrast to mRNA changes, Egr-1 protein (Fig. 2B) did not increase above control levels in any brain region in response to $\mathrm{HI}$ or $\mathrm{O}_{2}$ concentration. Egr-1 protein decreased in the cortex in response to $\mathrm{HI}$ when compared with controls. There was no significant difference in Egr-1 protein in the hippocampus or brainstem. There was only a very weak correlation of protein content with $\mathrm{CD}\left(r^{2}=0.42\right)$ in the cortex and with $\operatorname{ROS}\left(r^{2}=0.18\right)$ in the hippocampus.

ROS analysis. ROS production (Fig. 3A) was significantly increased only in the hippocampus, and only in response to HI (H21 and H100) $(p<0.02)$. ANOVA indicated that there was no additional difference in ROS production due to $100 \% \mathrm{O}_{2}$ in the hippocampus. Neither $\mathrm{HI}$ nor $\mathrm{O}_{2}$ resuscitation induced ROS production above control levels in the cortex. ROS were not detectable in the brainstem under any condition.

CD analysis. CD (Fig. 3B), was increased significantly in the hippocampus in response to HI $(p<0.05)$. There was an additional trend $(p=0.07)$ for increased $\mathrm{CD}$ after administration
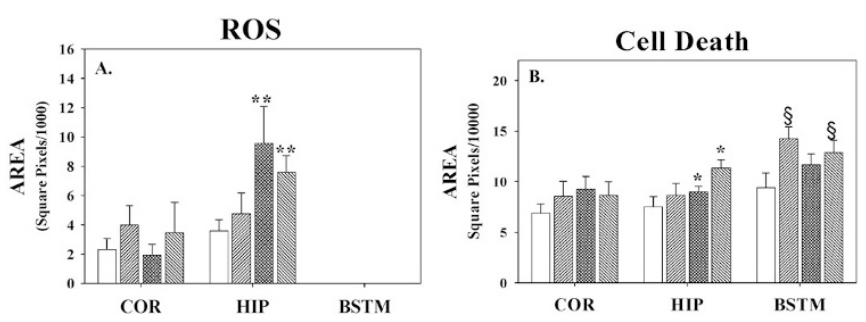

Figure 3. ROS and CD with HI/R in cortex (COR), hippocampus $(H I P)$, and brainstem (BSTM). (A) ROS. (B) CD. Open bars represent C21 $(n=7)$; left-hashed bars represent $\mathrm{C} 100(n=7)$; cross-hashed bars represent $\mathrm{H} 21$ $(n=7)$; right-hashed bars represent $\mathrm{H} 100(n=7) .{ }^{*} \mathrm{HI}(\mathrm{H} 21$ and H100) groups different from control groups (C21 and $\mathrm{C} 100 ; p<0.05)$. **HI groups different from control groups $(p<0.01)$. §Animals that received $100 \% \mathrm{O}_{2}$ (C100 and H100) different from those that received 21\% $\mathrm{O}_{2}(p<0.05)$. 
of $100 \% \mathrm{O}_{2}$ (C100 and $\left.\mathrm{H} 100\right)$ compared with $21 \% \mathrm{O}_{2}$ in the hippocampus. In the brainstem, administration of $100 \% \mathrm{O}_{2}$ resulted in a significant increase in CD compared with $21 \% \mathrm{O}_{2}$ $(p<0.05)$. In the cortex, there was no significant change in $\mathrm{CD}$ induced by $\mathrm{HI}$ or resuscitative $\mathrm{O}_{2}$ compared with control.

Resuscitation score. Despite a significantly higher $\mathrm{PaO}_{2}$ $(p<0.001)$ throughout resuscitation (Table $\left.1, \mathrm{~T}_{120}\right)$ in the groups resuscitated with $100 \% \mathrm{O}_{2}$, there was no difference in the resuscitation score, suggesting that the quality of resuscitation was similar in $\mathrm{H} 21$ and $\mathrm{H} 100$ animals. Clinically, $21 \% \mathrm{O}_{2}$ was found to be as effective as $100 \% \mathrm{O}_{2}$ for resuscitation (Fig. 4). Although this scoring system is limited in clinical applicability, the results do refute the concern that $21 \% \mathrm{O}_{2}$ would not be as effective in restoring cardiorespiratory stability as $100 \% \mathrm{O}_{2}$.

\section{DISCUSSION}

The results of the present study demonstrated the following in the neonatal piglet: 1) HI/R rapidly increased Egr-1 mRNA expression in all regions of the brain studied however, the magnitude of mRNA expression was regionally heterogeneous. 2) Egr-1 protein did not acutely increase with the increase of mRNA. 3) CD and ROS formation increased with $\mathrm{HI} / \mathrm{R}$ in the hippocampus but not in other structures studied. 4) $\mathrm{CD}$ was increased in the brainstem due solely to the administration of $100 \% \mathrm{O}_{2} .5$ ) By our physiologic measure, resuscitation with $100 \% \mathrm{O}_{2}$ was not superior to room air.

The increase in Egr-1 mRNA is consistent with other studies of Egr-1 and other immediate early genes in response to $\mathrm{HI}$ or HI/R. However, the magnitude and distribution of mRNA in the present study was different from other studies. The increase in Egr-1 mRNA expression in the brainstem (5-fold that in the cortex and 3-fold that in the hippocampus) was unexpected. Few studies have focused on the brainstem expression of Egr-1. Reddy and Zawia (7) demonstrated increasing expression of Egr-1 in the brainstem during postnatal development in the rat, even after neuronal proliferation and elaboration are complete, but did not quantitate it. Stress induction of Egr-1 mRNA also has been reported in the newborn rat, with increases observed within $15 \mathrm{~min}$ after electroconvulsive shock (8). Honkaniemi et al. observed intense induction in the hippocampus within $1 \mathrm{~h}$ after HI/R in adult gerbils (3) and after middle cerebral artery occlusion in the rat (2), with milder expression in the cortex as we observed. Honkaniemi et al. also found, after HI/R, mRNA

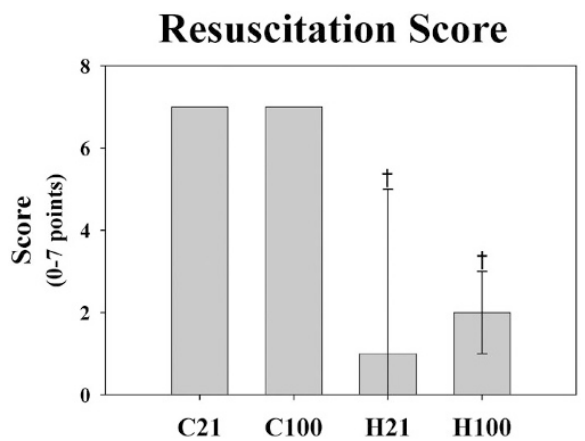

Figure 4. Physiologic resuscitation score comparing $21 \%$ and $100 \% \mathrm{O}_{2} . \dagger \mathrm{HI}$ $(\mathrm{H} 21$ and H100) groups different from control groups (C21 and C100; $p<$ $0.001)$. expression was decreased in most brain areas by $24 \mathrm{~h}$ but was still elevated in the CA1 neurons destined to die. Snyder-Keller et al. (9) reported that Egr-1 is under glutamatergic control in the newborn rat. Thus, the Egr-1 expression may reflect the increase in extracellular glutamate that occurs in the piglet (10) and neonatal rat (11) with HI. Thus, Egr-1 may be a marker of impending or ongoing excitatory amino acid damage.

Despite the large increase in mRNA, we did not observe an increase in Egr-1 protein. Kiessling et al. (12) also observed an increase in Egr-1 mRNA without an associated rise in protein in the CA1 region of the hippocampus. However, in other areas of the hippocampus less vulnerable to HI/R, protein did rise. Kiessling et al. hypothesized that the areas able to mount a protein response to the HI/R-associated mRNA increase may be destined to survive. In a milder form of $\mathrm{HI} / \mathrm{R}$, Johansson et al. (13) observed an early increase in Egr-1 mRNA that was paralleled by changes in protein. The "at risk" area that increased its protein did not show significant damage at $7 \mathrm{~d}$. Perhaps the large increase in mRNA without an increase in protein in the present study reveals a vulnerability that may have implications for deficits seen in newborns after asphyxia.

The mechanism for the poor protein production after HI has been previously examined. The protein synthesis paradox has been termed the unfolded protein response (14). The unfolded protein response is a stress response to cerebral ischemia in brain regions where the blood supply has been reduced below the threshold to meet the energy demands of the cells. Protein synthesis is severely suppressed, presumably by endoplasmic reticulum dysfunction and an inability to appropriately fold proteins. This inhibition of protein synthesis machinery occurs in both vulnerable and resistant cells. The distinguishing factor between the two cell types is that vulnerable cells never regain normal rates of protein synthesis $(15,16)$.

The concept of the unfolded protein response also raises the question of whether this mechanism is harmful or beneficial to long-term tissue survival. Shutting down synthesis of proteins would be detrimental, but preventing production of proteins involved in apoptosis could be critical to viability (16). Likewise, the expression of Egr-1 protein is immediately harmful and induces such maladaptive vascular responses as inflammation and thrombogenesis (5). In contrast, Egr-1 induction as late as $12-30 \mathrm{~d}$ post-ischemia is associated with improved neurologic outcome (13). Thus, the expression and function of Egr-1 is a complex phenomenon as seen in our study, and likely its role can be neuroprotective or neurotoxic depending on the location and precise timing of its expression.

Alternative interpretations of our data must be considered. The timing of our analysis could be responsible for failure to observe the synthesis of protein. As we terminated the animals in our experiments after $1 \mathrm{~h}$ of resuscitation, enough time may not have elapsed for de novo protein synthesis. However, others have observed early increases in protein by $1 \mathrm{~h}$ of resuscitation $(5,12,13)$. One must consider that the absence of an increase in protein found in our study may not be due to inhibition of protein synthesis but rather due to increased protein degradation. Our data cannot address this possibility. In addition, it must be acknowledged that the methodology for protein analysis is semi-quantitative and, thus, somewhat in- 
sensitive to small changes in protein. However, there was no trend or indication the protein levels increased even with a 15 -fold increase in mRNA in the brainstem.

The data from our study did not indicate that there was a general correlation between early CD or ROS with Egr-1 expression in the brain. However, we did measure an increase in both acute CD and ROS in the hippocampus, the most HI-sensitive area we studied. We infer that the $\mathrm{CD}$ we measured was necrotic, and perhaps mediated by excitatory amino acids or directly by energy failure. This is consistent with the observation of Martin et al. (17) that neuronal death after $\mathrm{HI}$ is primarily necrosis within the first $24 \mathrm{~h}$ after $\mathrm{HI}$ in the piglet. The time of evaluation was too short to accurately determine apoptotic CD. This is consistent with the data of Munkeby et al. (18), who observed cellular injury (glycerol release) within $30 \mathrm{~min}$ of resuscitation, and Martin et al., within $3 \mathrm{~h}$ of $\mathrm{HI}$ in the striatum of the piglet. However, our data did not reveal any additional CD or ROS production in any area studied due to resuscitation with $100 \% \mathrm{O}_{2}$ as compared with animals resuscitated with $21 \% \mathrm{O}_{2}$, which contradicts the enhanced cell injury observed by Munkeby $e t a l$. (18). The reason for this discrepancy is not clear. It may be that the striatum is more sensitive to $100 \% \mathrm{O}_{2}$ than the structures we studied or that extra cellular glycerol may be indicative of injury processes that propidium iodide is not. The fact that we chose to examine ROS in vitro post mortem probably reduced our ability to determine changes when they may have been most critical, at the onset of resuscitation. It is possible that there was ROS formation at that time but the ROS were removed by the end of resuscitation. Martin et al. (17) found glutathione levels depleted at the earliest time examined after $\mathrm{HI}(3 \mathrm{~h})$. Further depletion was not observed in their studies. In our studies, ROS was not detectable in the brainstem in any of the experimental groups. This may be indicative of better scavenging capabilities of the brainstem and possibly the cortex or that there was continued ROS production in the hippocampus that overwhelmed the antioxidant defenses. This was independent of resuscitative $\mathrm{O}_{2}$ concentration. Thus, room air must supply sufficient $\mathrm{O}_{2}$ to maintain elevated ROS in the hippocampus and perhaps energize the antioxidant systems in the brainstem and cortex.

Even without measured increases in ROS in the brainstem, we observed that administration of $100 \% \mathrm{O}_{2}$ caused additional CD. This was independent of whether or not the animals had previously been hypoxic. Therefore, $100 \%$ may have been toxic to some brainstem cells. However, our data do not allow us to speculate on the mechanism of toxicity. This could potentially have significance in newborns who receive $\mathrm{O}_{2}$ therapy and have brainstem associated sequelae.

The use of $21 \% \mathrm{O}_{2}$ had no negative impact on cardiorespiratory recovery as assessed by our resuscitation score and was as effective as $100 \% \mathrm{O}_{2}$ resuscitation in physiologic recovery following HI. A limitation of our data are that this resuscitation score has not been validated with neurologic outcome. However, our findings are consistent with both the animal and human literature in that the majority of studies investigating room air resuscitation have concluded that $21 \% \mathrm{O}_{2}$ is as effective as $100 \% \mathrm{O}_{2}$ and some have found evidence that $21 \%$ $\mathrm{O}_{2}$ is superior to $100 \% \mathrm{O}_{2}$ for resuscitation (19-21).

\section{CONCLUSIONS}

Egr-1 mRNA expression is rapidly enhanced by HI/R but protein levels are not. Egr-1 protein levels may be tightly regulated via impaired protein production or increased degradation in an attempt to diminish neurotoxicity or to enhance plasticity. Room air and $100 \% \mathrm{O}_{2}$ resuscitation had a similar effect on Egr-1, CD, and ROS after HI. However, 100\% $\mathrm{O}_{2}$ administration was associated with increased $\mathrm{CD}$ in the brainstem independent of $\mathrm{HI}$.

Acknowledgments. The authors thank Ajay Verma, M.D., $\mathrm{Ph} . \mathrm{D}$., for his critical advice and the use of his laboratory facilities; David Jacobowitz, Ph.D., for his guidance and assistance with protein analysis; and Jozsef Czege, Ph.D., and Tom Baginski for their assistance with fluorescence microscopy and digital image analysis.

\section{REFERENCES}

1. Datta R, Taneja N, Sukhatme VP, Qureshi SA, Weichselbaum R, Kufe DW 1993 Reactive oxygen intermediates target $\mathrm{CC}(\mathrm{A} / \mathrm{T}) 6 \mathrm{GG}$ sequences to mediate activation of the early growth response 1 transcription factor gene by ionizing radiation. Proc Natl Acad Sci U S A 90:2419-2422

2. Honkaniemi J, States BA, Weinstein PR, Espinoza J, Sharp FR 1997 Expression of zinc finger immediate early genes in rat brain after permanent middle cerebral artery occlusion. J Cereb Blood Flow Metab 17:636-646

3. Honkaniemi J, Sharp FR 1996 Global ischemia induces immediate-early genes encoding zinc finger transcription factors. J Cereb Blood Flow Metab 16:557-565

4. Gashler A, Sukhatme VP 1995 Early growth response protein 1 (Egr-1): prototype of a zinc-finger family of transcription factors. Prog Nucleic Acid Res Mol Biol 50:191-224

5. Yan SF, Fujita T, Lu J, Okada K, Shan Zou Y, Mackman N, Pinsky DJ, Stern DM 2000 Egr-1, a master switch coordinating upregulation of divergent gene families underlying ischemic stress. Nat Med 6:1355-1361

6. Ramji S, Ahuja S, Thirupuram S, Rootwelt T, Rooth G, Saugstad OD 1993 Resuscitation of asphyxic newborn infants with room air or $100 \%$ oxygen. Pediatr Res 34:809-812

7. Reddy GR, Zawia NH 2000 Lead exposure alters Egr-1 DNA-binding in the neonatal rat brain. Int J Dev Neurosci 18:791-795

8. Jung HY, Kang UG, Joo YH, Cho SC, Jeon SH, Park JB, Kim YS 1998 Electroconvulsive shock does not induce c-fos and junB, but TIS1 and TIS8/zif-268, in neonatal rat hippocampus. Brain Res Dev Brain Res 108:303-306

9. Snyder-Keller A, Chandra R, Lin Y, Mitchell ES 2002 Basal EGR-1 (zif268, NGFI-A, Krox-24) expression in developing striatal patches: role of dopamine and glutamate. Brain Res 958:297-304

10. Froen JF, Amerio G, Stray-Pedersen B, Saugstad OD 2002 Detrimental effects of nicotine and endotoxin in the newborn piglet brain during severe hypoxemia. Biol Neonate 82:188-196

11. Vannucci RC, Brucklacher RM, Vannucci SJ 1999 CSF glutamate during hypoxiaischemia in the immature rat. Brain Res Dev Brain Res 118:147-151

12. Kiessling M, Stumm G, Xie Y, Herdegen T, Aguzzi A, Bravo R, Gass P 1993 Differential transcription and translation of immediate early genes in the gerbil hippocampus after transient global ischemia. J Cereb Blood Flow Metab 13:914-924

13. Johansson IM, Wester P, Hakova M, Gu W, Seckl JR, Olsson T 2000 Early and delayed induction of immediate early gene expression in a novel focal cerebral ischemia model in the rat. Eur J Neurosci 12:3615-3625

14. Paschen W, Linden T, Doutheil J 1998 Effects of transient cerebral ischemia on hsp40 mRNA levels in rat brain. Brain Res Mol Brain Res 55:341-344

15. Herdegen T, Leah JD 1998 Inducible and constitutive transcription factors in the mammalian nervous system: control of gene expression by Jun, Fos and Krox, and CREB/ATF proteins. Brain Res Brain Res Rev 28:370-490

16. DeGracia DJ, Montie HL 2004 Cerebral ischemia and the unfolded protein response. J Neurochem 91:1-8

17. Martin LJ, Brambrink AM, Price AC, Kaiser A, Agnew DM, Ichord RN, Traystman RJ 2000 Neuronal death in newborn striatum after hypoxia-ischemia is necrosis and evolves with oxidative stress. Neurobiol Dis 7:169-191

18. Munkeby BH, Borke WB, Bjornland K, Sikkeland LI, Borge GI, Halvorsen B, Saugstad OD 2004 Resuscitation with 100\% O2 increases cerebral injury in hypoxemic piglets. Pediatr Res 56:783-790

19. Vento M, Asensi M, Sastre J, Garcia-Sala F, Pallardo FV, Vina J 2001 Resuscitation with room air instead of $100 \%$ oxygen prevents oxidative stress in moderately asphyxiated term neonates. Pediatrics 107:642-647

20. Goplerud JM, Kim S, Delivoria-Papadopoulos M 1995 The effect of post-asphyxial reoxygenation with $21 \%$ vs. $100 \%$ oxygen on $\mathrm{Na}+, \mathrm{K}(+)$-ATPase activity in striatum of newborn piglets. Brain Res 696:161-164

21. Temesvari P, Karg E, Bodi I, Nemeth I, Pinter S, Lazics K, Domoki F, Bari F 2001 Impaired early neurologic outcome in newborn piglets reoxygenated with $100 \%$ oxygen compared with room air after pneumothorax-induced asphyxia. Pediatr Res 49:812-819 